九州大学学術情報リポジトリ

Kyushu University Institutional Repository

\title{
Optimum Spray Method for Paprika Cultivation Sites under Structure and Pest Control Effects According to Spray Water Volumes
}

Jin, Na Young

Department of Applied Biology, College of Agriculture and Life Sciences, Chungnam National University

Lee, You Kyoung

Department of Applied Biology, College of Agriculture and Life Sciences, Chungnam National University

\section{Lee, Bo Ram}

Department of Applied Biology, College of Agriculture and Life Sciences, Chungnam National University

\section{Kim, Yu Seop}

Department of Applied Biology, College of Agriculture and Life Sciences, Chungnam National University

他

https://doi.org/10.5109/1564088

出版情報：九州大学大学院農学研究院紀要. 61 (1)，pp.95-101，2016-02-29. Faculty of Agriculture， Kyushu University

バージョン :

権利関係 : 


\title{
Optimum Spray Method for Paprika Cultivation Sites under Structure and Pest Control Effects According to Spray Water Volumes
}

\author{
Na Young JIN ${ }^{1}$, You Kyoung LEE ${ }^{1}$, Bo Ram LEE ${ }^{1}$, Yu Seop KIM ${ }^{1}$, Hee Ji KIM${ }^{1}$, \\ Young Shin KIM ${ }^{2}$, Chi Hwan LIM ${ }^{2}$, Young Nam YOUN ${ }^{1}$, \\ Chisa YASUNAGA-AOKI* and Yong Man YU ${ }^{1 *}$
}

\author{
Laboratory of Insect Pathology and Microbial Control, Institute of Biological Control, \\ Faculty of Agriculture, Kyushu University, Fukuoka 812-8581, Japan \\ (Received November 10, 2015 and accepted November 19, 2015)
}

\begin{abstract}
Pesticides were sprayed on a paprika cultivation site under structure using two types of sprayers (a remote control sprayer and a U-shaped sprayer). Next, the impact of the amount of pesticide used, the amount of active components, and spray water volumes on pest control were reviewed. As representative pests that are not easily controlled in cultivation sites under structure, two species of pests (Bemisia tabaci and Frankliniella occidentalis) were used. When the pesticide Pyrifluquinazon 10\% WG was sprayed using remote control sprayers, particularly in the case of $B$. tabaci, a control value of $82.5 \%$ was identified when water-sensitive paper discolored into blue in the entire experimental plot. A control value of $42.6 \%$ was shown when water-sensitive paper discolored into blue in approximately a half of the experimental plot. However, the presence of pests increased greatly before the pesticide was sprayed in dead zones where the pesticide was not attached to the plant. Meanwhile, an experiment to discover the optimum pesticide spray volume with the use of U-shaped sprayers was conducted with ten paprika plants. In cases in which $5 \mathrm{~L}$ of Pyrifluquinazon 10\% WG were applied as a pesticide, the B. tabaci control effect was $100 \%$. Additionally, $2.5 \mathrm{~L}$ of the pesticide solution, which is one-half in volume, also showed $100 \%$ efficiency in controlling $B$. tabaci. In the case of $F$. occidentalis, when $5 \mathrm{~L}$ of Spinetoram $5 \%$ WG, Cyantraniliprole $5 \%$ EC, and Abamectin 1.8\% EC were sprayed, control effects of $91.6 \%, 83.2 \%$, and $82.8 \%$ were found, respectively. When the volume of the pesticide solutions was reduced to $2.5 \mathrm{~L}$, control effects similar to those of $5 \mathrm{~L}$ were shown, reaching $95.6 \%, 80.4 \%$, and $86.8 \%$, respectively. The residual amounts of active components attached to paprika leaves averaged $5.36\left(\mu \mathrm{g} / 50 \mathrm{~cm}^{2}\right)$ in the case of Abamectin 1.8\% EC and $28.80\left(\mu \mathrm{g} / 50 \mathrm{~cm}^{2}\right)$ in the case of Spinetoram $5 \%$ WG
\end{abstract}

Key words: Bemisia tabaci, Frankliniella occidentalis, Remote controlled sprayer, Spray water volume, U-shaped sprayer

\section{INTRODUCTION}

First cultivated in South Korea in 1994, the cultivation area and output of paprika have continuously increased (Kim et al., 2013; Cho et al., 2011). As of 2011, the cultivation area reached approximately 450 ha, and the annual output amounted to approximately 400,000 tons (Lee et al., 2013). The most problematic pests in paprika cultivation under structure are sucking pests like thrips, leaf mites, white flies, aphids, and moths (Kim et al., 2008). These small insects are difficult to control because they oviposit several ten or several hundred eggs per cycle and undergo several life cycles per year, which rapidly increases their numbers. They also live in places not exposed to chemical control. Furthermore, efforts to control them are continuously required since their resistance to pesticides develops rapidly because of their wide host ranges and short genera-

Department of Applied Biology, College of Agriculture and Life Sciences, Chungnam National University, Daejon 305-764, Korea

2 Department of Bio-Environmental Chemistry, College of Agricultural Biology and Life Sciences, Chungnam National University, Daejeon 305-764, Korea

* Joint corresponding authors (E-mail: youngnam@cnu.ac.kr; yasunaga@grt.kyushu-u.ac.jp) tional periods (Shim et al., 1997). Recently, because these pests have rapidly developed resistance to existing registered pesticides, highly concentrated pesticides have been used, the frequency of pesticide application has increased, or large numbers of similar pesticides have been mixed. However, these responses have been a major cause of pesticide abuse (Jin et al., 2014). Even in the case of pesticides with good control effects, if the amount used increases, the selection pressure will increase, leading to a greater possibility that pests will develop resistance and that the life cycle of the pesticides will decrease. Therefore, pests should be controlled using the minimum amounts of pesticides and using optimum spraying methods (Choi et al., 2005). However, control abilities according to the types of agricultural materials, such as sprayer nozzles and optimum doses of pesticides, have not been standardized.

Currently, pesticides are sprayed in paprika cultivation sites under structure using apparatuses such as remote control sprayers and high-pressure sprayers to control pests. High-pressure sprayers are advantageous in that the pesticides are evenly attached to plants so that plants can quickly absorb the pesticides. However, using high-pressure sprayers is inconvenient because large amounts of time and labor are required. They are also harmful to human bodies (Kim, 2012), and their control 
effects may be poor depending on those who uses them, as pesticides may not be attached to the back or medial side of leaves (Jin et al., 2014). In addition, the sizes of sprayed particles and sprayed volumes per hour vary with pressure and nozzles, which are diverse among products from different companies (Son et al., 2012). Remote control sprayers are advantageous in that not only are the particles atomized so that pesticides can be evenly applied but particle size can also be adjusted according to the crop (Min et al., 2007). However, they are unable to evenly distribute pesticides in wide cultivation sites under structure. Therefore, improved pesticide spraying methods are urgently required to standardize pest control, to reduce the amounts of pesticides used, and to minimize the exposure of farmers to pesticides.

This study analyzed the characteristics of applying pesticides using remote control sprayers and high-pressure sprayers in paprika cultivation sites under structure. The study also determined whether chemicals were evenly sprayed using the two sprayer types so that dead zones would not occur in packing, which was checked using water-sensitive paper. The amount of active components of pesticides attached to plants were analyzed to see whether the pesticides were evenly attached, and attempts were made to standardize spraying methods that produce maximum control effects with optimum amounts of active components.

\section{MATERIALS AND METHODS}

\section{Experimental material}

The following pesticides were commercially purchased and diluted to multiples safe for use before beginning the experiment (Table 1): Pyrifluquinazon 10\% Water Dispersible Granule (or Fanfare) was used to control Bemisia tabaci present on paprika, and Cyantraniliprole 5\% Emulsifiable Concentrate (or Procure), Abamectin 1.8\% Emulsifiable Concentrate (AllStar), and Spinetoram 5\% Water Dispersible Granule (or Delicate) were used to control Frankliniella occidentalis. Remote control sprayers (nano (ultrafine particle) fog unmanned pest control machine, C \& Tech) and U-shaped high-pressure sprayers (Engine sprayer (BCET-25A), Korea B \& C) were used.

Table 1. Sprayers type and pesticide to target pests

\begin{tabular}{ccl}
\hline Sprayers type & Target pest & \multicolumn{1}{c}{ Pesticide } \\
\hline Remote control & Bemisia tabaci & Pyrifluquinazon 10\% WG \\
\cline { 2 - 3 } sprayer & Frankliniella & Cyantraniliprole 5\% EC \\
U-shaped sprayer & occidentalis & Abamectin 1.8\% EC \\
& & Spinetoram 5\% WG \\
\hline
\end{tabular}

\section{Target crop and test place}

The test crop paprika of the rubato variety, with a length between $2 \mathrm{~m}$ and $2 \mathrm{~m} 30 \mathrm{~cm}$, was used in the experiment. The crop was cultivated in a glass greenhouse farm located in Yangnam-myeon, Gyeongju-si,

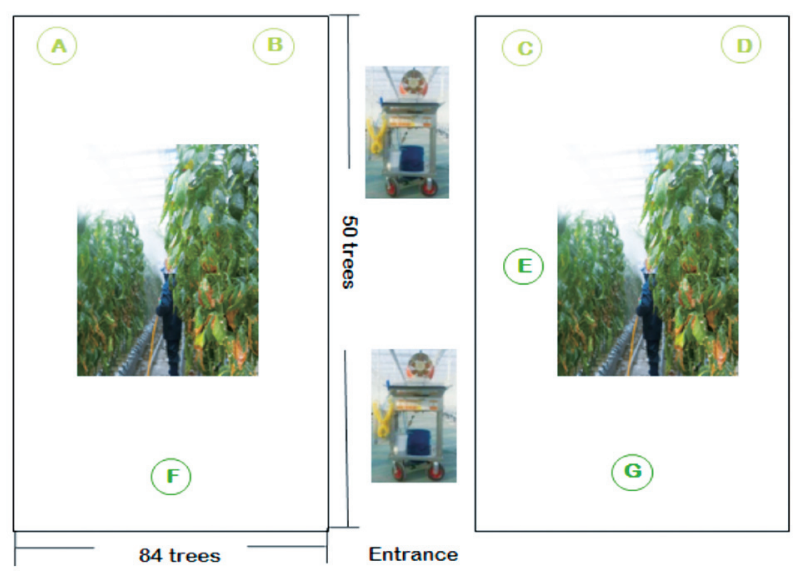

Fig. 1. Experiment section of occurrence zone of Bemisia tabaci (A, B, C, D) and Frankliniella occidentalis (A, B, C, D, E, F, G).

Gyeongsangbuk-do. The greenhouse's area is approximately $6600 \mathrm{~m}^{2}$, and the two types of sprayers were used in conventional methods. The major target pests were B. tabaci and F. occidentalis. Experimental plots were installed, as shown in Fig. 1.

\section{Investigation of water-sensitive paper states and the amount of active components according to sprayers}

In the greenhouse field experiment, pesticides were sprayed using remote control and high-pressure sprayers. Control effects according to pesticide treatment method were then reviewed. Experimental sections were divided according to the number of pests present, as shown in Fig. 1 and water-sensitive paper (water sensitive paper $52 \times 76 \mathrm{~mm}$, TeeJet Tech. Switzerland) and patches were installed in all experimental sections before spraying the pesticides. The water-sensitive paper (Chung et al., 1997; Koo, 2007) was attached to the front and back of leaves to measure the uniformity of pesticide attachment by determining the degree to which the water-sensitive paper was coated after each pesticide spray. To evaluate the amount of active components of pesticides per unit area, patches for skin exposure measurement (Kim et al., 2011) and $\alpha$-cellulose paper (Whatman 17CHR, 46 $\times 57 \mathrm{~cm}$, Cat. No.3017-915) were cut to $10 \mathrm{~cm} \times 10 \mathrm{~cm}$. The paper pieces were fixed in pockets made of aluminum foil, and the patches were installed on the upper and lower parts of paprika stems. The experimental results were analyzed using two analyzers, HPLC Hewlet Packard 1090 (USA) and LC/MS Shimadzu 2020 (Japan), in the Department of Bio-Environmental Chemistry of Chungnam National University.

\section{Investigation of pest control values according to sprayers}

To investigate pest control effects, pest densities were investigated using visual examination before pesticide treatment. To control B. tabaci, Pyrifluquinazon 10\% WG (Fanfare) was diluted to the multiple for safe use and was distributed using remote control sprayers and 
U-shaped high-pressure sprayers. To control F. occidentalis, Cyantraniliprole 5\% EC (Procure), Abamectin 1.8\% EC (All-Star), and Spinetoram 5\% WG (Delicate) were diluted to the multiple for safe use and sprayed. The control values for $B$. tabaci and $F$. occidentalis, as specified in a 2015 book on pesticide tester education (Korea Crop Protection Association, 2015), were observed in the experiment. Before the pesticide treatment, 50 pests per section were identified. The number of live pests was examined before the pesticide treatment and three and seven days after the pesticide treatment to calculate control values.

\section{Investigation of pest control effects of optimum pesticide spray water volumes}

To investigate the optimum pesticide spray water volumes required to control B. tabaci and $F$. occidentalis, treatment plots were set with ten plants per section. The plants were divided into three repetition sections per pesticide, and one section was left as a space between the sections to prevent the pesticides from mixing. Using U-shaped high-pressure sprayers, $5 \mathrm{~L}$ of each test pesticide solution (diluted to the standard multiple specified for safe use) were sprayed once in each section so that the solution sufficiently flowed on the crop (Lee et al., 2013). Next, reduced amounts of the pesticide solution, $2.5 \mathrm{~L}$ and $1.25 \mathrm{~L}$, were sprayed once in each section. The number of pests exceeding 50 per section was identified. To measure pest control values, the number of live pests was examined before pesticide treatment, as well as three and seven days after pesticide treatment.

\section{RESULTS AND DISUCUSSION}

Since research and development of chemical pesticides have not been active for several years due to concentrated efforts on environmentally friendly agricultural products, there are no clear study results related to chemical pesticides. No case has been reported in which methods of using pesticides that are effective for pest control and safe to humans (ranging from pesticide purchase by farmers to the spray of pesticides) are studied, developed, and standardized. Diverse factors affect pest control in crops, including pesticide effects (whether resistance is expressed), spraying workers' habits, the number of sprays, the types of sprayers, and the locations of pest occurrence. Therefore, the purpose of the present experiment is to identify proper pesticide spraying methods for paprika cultivation sites under structure and to reduce the amount of pesticide used. The experiment specifically examined whether pesticides were properly sprayed according to the plant length, the location of target crops by type of pesticide sprayer (remote control sprayer, high-pressure sprayer), the amount of active components in the pesticides, and the minimum spray water volume that provides optimum control effects.

\section{Water-sensitive paper results and bemisia tabaci control effects by type of sprayer}

To find dead zones in the paprika cultivation site under structure, water-sensitive paper patches were randomly attached to the front and back of leaves of different length paprika plants. Within the cultivation site

Table 2. Mortalities of Bemisia tabaci to each section according to the sprayers type

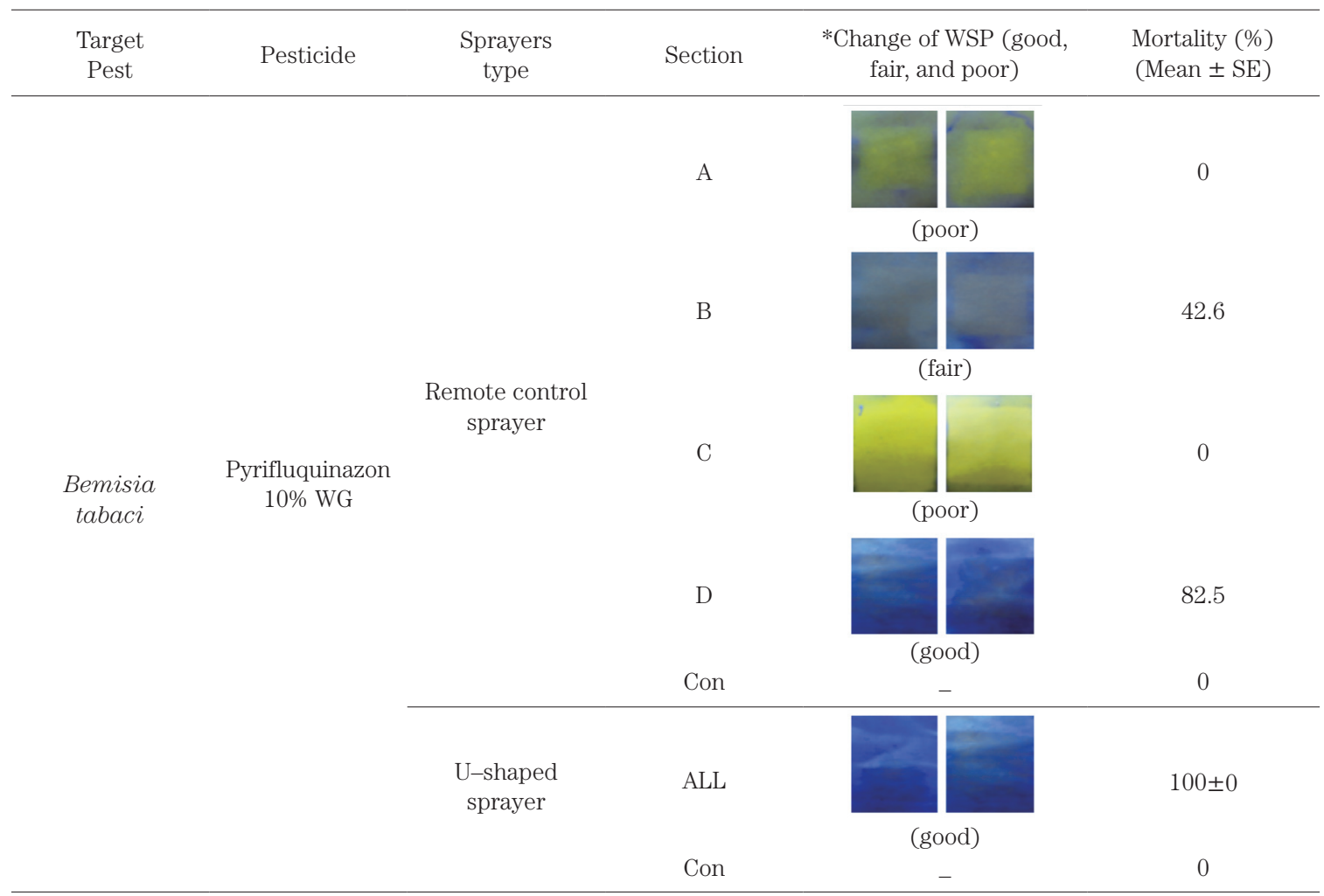

* Water-Sensitive Paper (WSP) results were divided randomly into good, fair, and poor, according to the pesticide dose. 
Table 3. Mortalities of Bemisia tabaci of Pyrifluquinazon 10\% WG with spray water volume

\begin{tabular}{|c|c|c|c|c|c|}
\hline \multirow{2}{*}{$\begin{array}{l}\text { Sprayers } \\
\text { type }\end{array}$} & \multirow{2}{*}{$\begin{array}{l}\text { Target } \\
\text { pest }\end{array}$} & \multirow{2}{*}{ Pesticide } & \multirow{2}{*}{$\begin{array}{l}\text { Application } \\
\text { Dose } \\
\text { (L/10 tree) }\end{array}$} & \multicolumn{2}{|c|}{$\begin{array}{c}\text { Mortality (\%) } \\
(\text { Mean } \pm \mathrm{SE})\end{array}$} \\
\hline & & & & $24 \mathrm{hr}$ & $72 \mathrm{hr}$ \\
\hline \multirow{4}{*}{$\begin{array}{l}\text { U-shaped } \\
\text { sprayer }\end{array}$} & \multirow{4}{*}{$\begin{array}{c}\text { Bemisia } \\
\text { tabaci }\end{array}$} & \multirow{3}{*}{$\begin{array}{c}\text { Pyrifluquinazon } \\
\text { 10\% WG }\end{array}$} & $5 \mathrm{~L}$ & $97.5 \pm 3.5$ & $100 \pm 0$ \\
\hline & & & $2.5 \mathrm{~L}$ & $95.5 \pm 8.7$ & $100 \pm 0$ \\
\hline & & & $1.25 \mathrm{~L}$ & $57.3 \pm 3.5$ & $65.7 \pm 3.7$ \\
\hline & & Con & - & 0 & 0 \\
\hline
\end{tabular}

under structure (the test place), test sections were set in four regions $(\mathrm{A}, \mathrm{B}, \mathrm{C}, \mathrm{D})$ opposite to the entrance to see the distribution of B. tabaci (Fig. 1). When pesticides were sprayed using remote control sprayers, the water-sensitive paper experienced the most discoloration in section D. Moderate discoloration was found in section B, and very little discoloration was present in sections A and C. As with the water-sensitive paper results, Pyrifluquinazon 10\% WG produced the highest pest mortality rate, reaching $82.5 \%$ in section $\mathrm{D}$ (where the water-sensitive paper was discolored the most). A mortality rate of $42.6 \%$ was found in section B (where the water-sensitive paper was moderately discolored), but the pest density increased compared to the density prior to the experiment in sections A and C (Table 2). When pesticide solutions were sprayed using remote control sprayers, pests were not controlled well in dead zones or regions with low attachment rates, although high control effects were shown in regions where pesticides were well sprayed. When testing the new type of minute particle unmanned sprays, even sprays of the same spray water volume were expected, but uneven sprays were produced, as can be seen in Table 2 . U-shaped, high-pressure sprayers are most commonly used in paprika farms. When pesticides were sprayed using high-pressure sprayers, water-sensitive paper was discolored to blue in all regions, and no dead zone was found. The pesticides were evenly sprayed in the entire spray region. In addition, Pyrifluquinazon 10\% WG showed a pest mortality of $100 \%$ (Table 2). Although the effectiveness of high-pressures sprayers depends on the manner in which the worker uses the device (including whether or not the pesticides are attached to the back or medial side of leaves), they should be effective for pest control if they are used properly to spray pesticides evenly.

\section{B. tabaci control effects of low spray volumes}

Domestic crop protectant guidelines only specify crop names, time of use, applicable pests, the appropriate season for and methods of use, and the amount of chemicals to be used in $20 \mathrm{~L}$ of water. The number of times of use and regulations for pesticide spray volumes per unit area have not been standardized. The methods of use simply instructs users to "spray evenly so that the pesticide solution is sufficiently spread on the crop," and this led to the development of resistance to registered pesticides so that the number of chemicals mixed into pesti- cides and the number of sprays gradually increased, resulting in safety problems due to abuse. Therefore, accurate pest control effects of pesticides according to spray volumes should be investigated. Based on the experimental results mentioned above, the pest control effects of Pyrifluquinazon 10\% WG at different spray water volumes, when evenly sprayed by high-pressure sprayers, were examined. When $5 \mathrm{~L}$ of the pesticide solution were sprayed (enough to cover ten plants with sufficient amounts of the pesticide), Pyrifluquinazon 10\% WG showed a control value of $97.5 \%$ after 24 hours and $100 \%$ after 72 hours. When $2.5 \mathrm{~L}$ of Pyrifluquinazon $10 \%$ WG were sprayed, a control value of $95.5 \%$ was shown after 24 hours and 100\% after 72 hours. On the other hand, when 1.25 L of Pyrifluquinazon 10\% WG was sprayed, lower control effects were shown: a control value of approximately $57.3 \%$ was shown after 24 hours and approximately $65.7 \%$ was shown after 72 hours (Table 3). Even when $2.5 \mathrm{~L}$ of the attached pesticide solution were sprayed, the control effects would be sufficient.

\section{Water-sensitive paper results and $\boldsymbol{F}$. occidentalis control effects according to sprayer types}

To measure the degree of pesticide deposit according to sprayer types, water-sensitive paper patches were randomly attached to the front and back of leaves in proportion to plant lengths. F. occidentalis occurred densely in the entire cultivation site under structure, and seven test sections (A, B, C, D, E, F, G) were set (Fig. 1). When pesticides were sprayed using remote control sprayers, the water-sensitive paper was not discolored in any of the seven regions (A, B, C, D, E, F, G). As with the watersensitive paper results, Spinetoram $5 \%$ WG showed no pest control effect (Table 4). As with the results of the experiment with $B$. tabaci, the experiment with remote control sprayers (a new type of unmanned minute particle sprayer) produced uneven results, as can be seen in Table 4. Therefore, minute particle sprayers used in large greenhouses, such as paprika cultivation sites under structure, should be developed so that they can evenly spray the same particles and chemical solutions so that pesticides can arrive at regions where pests are present. When pesticides were sprayed using high-pressure sprayers, the water-sensitive paper was discolored to blue in all regions, indicating that the pesticide was evenly distributed. In addition, Spinetoram 5\% WG showed high pest control values reaching $91.6 \%$ after 72 hours of 
Table 4. Mortalities of Frankliniella occidentalis to each section according to the sprayers type

\begin{tabular}{|c|c|c|c|c|c|}
\hline $\begin{array}{c}\text { Target } \\
\text { pest }\end{array}$ & Pesticide & $\begin{array}{l}\text { Sprayers } \\
\text { type }\end{array}$ & Section & $\begin{array}{l}\text { *Change of WSP (good, } \\
\text { fair, and poor) }\end{array}$ & $\begin{array}{r}\text { Mortality (\%) } \\
(\text { Mean } \pm \text { SE) }\end{array}$ \\
\hline \multirow{4}{*}{$\begin{array}{l}\text { Frankliniella } \\
\text { occidentalis }\end{array}$} & \multirow{4}{*}{$\begin{array}{l}\text { Spinetoram } \\
5 \% \mathrm{WG}\end{array}$} & $\begin{array}{l}\text { Remote control } \\
\text { sprayer }\end{array}$ & ALL & (poor) & 0 \\
\hline & & & Con & - & 0 \\
\hline & & $\begin{array}{l}\text { U-shaped } \\
\text { sprayer }\end{array}$ & ALL & & $91.6 \pm 2.5$ \\
\hline & & & Con & - & 0 \\
\hline
\end{tabular}

* Water-Sensitive Paper (WSP) results were divided randomly into good, fair, and poor, according to the pesticide dose.

being sprayed (Table 4). As with the results of experiment with Bemisia tabaci using high-pressure sprayers, high-pressure sprayers should be effective for pest control if used properly by the workers so that pesticides are evenly distributed.

\section{F. occidentalis control effects of low spray volumes}

F. occidentalis control effects of Spinetoram 5\% WG, Cyantraniliprole 5\% EC, and Abamectin 1.8\% EC at different spray water volumes were reviewed. Since these three chemicals were not repeatedly used in the test farm, the experiment was conducted with the expectation that no resistance would be identified. When $5 \mathrm{~L}$ of the pesticide solution were sprayed, Spinetoram 5\% WG showed a control effect of approximately $87.5 \%$ after 24 hours and approximately $91.6 \%$ after 72 hours. When $2.5 \mathrm{~L}$ were sprayed, Spinetoram 5\% WG showed a control effect of approximately $90.3 \%$ after 24 hours and approxi- mately $95.6 \%$ after 72 hours. On the other hand, when 1.25 L of Spinetoram 5\% WG was sprayed, lower control effects of $43.5 \%$ were shown after 24 hours and approximately 55.2\% after 72 hours (Table 5). When $5 \mathrm{~L}$ Cyantraniliprole 5\% EC were sprayed, high control effects were shown, which reached approximately $75.5 \%$ after 24 hours and $83.2 \%$ after 72 hours. Even when $2.5 \mathrm{~L}$ were sprayed, similar control effects were identified and reached approximately $76.3 \%$ after 24 hours and approximately $80.4 \%$ after 72 hours. However, when $1.25 \mathrm{~L}$ were sprayed, lower control effects were identified, reaching approximately 53.5\% 24 after hours and approximately $58.8 \%$ after 72 hours (Table 6). Abamectin 1.8\% EC showed similar pest control effects to that of the two previously mentioned pesticides. When $5 \mathrm{~L}$ were sprayed, control values reached approximately $80.5 \%$ after 24 hours and approximately $82.8 \%$ after 72 hours. Likewise, when $2.5 \mathrm{~L}$ were sprayed, the control value reached

Table 5. Mortalities of Frankliniella occidentalis of Spinetoram 5\% WG with spray water volume

\begin{tabular}{|c|c|c|c|c|c|}
\hline \multirow{2}{*}{$\begin{array}{l}\text { Sprayers } \\
\text { type }\end{array}$} & \multirow{2}{*}{$\begin{array}{l}\text { Target } \\
\text { pest }\end{array}$} & \multirow[t]{2}{*}{ Pesticide } & \multirow{2}{*}{$\begin{array}{c}\text { Application } \\
\text { dose } \\
\text { (L/10 tree) }\end{array}$} & \multicolumn{2}{|c|}{$\begin{array}{c}\text { Mortality (\%) } \\
\text { (Mean } \pm \mathrm{SE} \text { ) }\end{array}$} \\
\hline & & & & $24 \mathrm{hr}$ & $72 \mathrm{hr}$ \\
\hline \multirow{4}{*}{$\begin{array}{l}\text { U-shaped } \\
\text { sprayer }\end{array}$} & \multirow{4}{*}{$\begin{array}{c}\text { Frankliniella } \\
\text { occidentalis }\end{array}$} & \multirow{3}{*}{$\begin{array}{c}\text { Spinetoram } \\
5 \% \mathrm{WG}\end{array}$} & $5 \mathrm{~L}$ & $87.5 \pm 2.5$ & $91.6 \pm 2.5$ \\
\hline & & & $2.5 \mathrm{~L}$ & $90.3 \pm 1.5$ & $95.6 \pm 3.7$ \\
\hline & & & $1.25 \mathrm{~L}$ & $43.5 \pm 2.5$ & $55.2 \pm 1.2$ \\
\hline & & Con & _- & 0 & 0 \\
\hline
\end{tabular}

Table 6. Mortalities of Frankliniella occidentalis of Cyantraniliprole 5\% EC with spray water volume

\begin{tabular}{|c|c|c|c|c|c|}
\hline \multirow{2}{*}{$\begin{array}{l}\text { Sprayers } \\
\text { type }\end{array}$} & \multirow{2}{*}{$\begin{array}{c}\text { Target } \\
\text { pest }\end{array}$} & \multirow[t]{2}{*}{ Pesticide } & \multirow{2}{*}{$\begin{array}{c}\text { Application } \\
\text { dose } \\
\text { (L/10 tree) }\end{array}$} & \multicolumn{2}{|c|}{$\begin{array}{c}\text { Mortality (\%) } \\
(\text { Mean } \pm \mathrm{SE} \text { ) }\end{array}$} \\
\hline & & & & $24 \mathrm{hr}$ & $72 \mathrm{hr}$ \\
\hline \multirow{4}{*}{$\begin{array}{l}\text { U-shaped } \\
\text { sprayer }\end{array}$} & \multirow{4}{*}{$\begin{array}{c}\text { Frankliniella } \\
\text { occidentalis }\end{array}$} & \multirow{3}{*}{$\begin{array}{c}\text { Cyantraniliprole } \\
\text { 5\% EC }\end{array}$} & $5 \mathrm{~L}$ & $75.5 \pm 3.0$ & $83.2 \pm 3.5$ \\
\hline & & & $2.5 \mathrm{~L}$ & $76.3 \pm 2.5$ & $80.4 \pm 2.7$ \\
\hline & & & $1.25 \mathrm{~L}$ & $53.5 \pm 2.5$ & $58.8 \pm 1.5$ \\
\hline & & Con & - & 0 & 0 \\
\hline
\end{tabular}


Table 7. Mortalities of Frankliniella occidentalis of Abamectin 1.8\% EC with spray water volume

\begin{tabular}{|c|c|c|c|c|c|}
\hline \multirow{2}{*}{$\begin{array}{l}\text { Sprayers } \\
\text { type }\end{array}$} & \multirow{2}{*}{$\begin{array}{l}\text { Target } \\
\text { pest }\end{array}$} & \multirow{2}{*}{ Pesticide } & \multirow{2}{*}{$\begin{array}{c}\text { Application } \\
\text { dose } \\
\text { (L/10 tree) }\end{array}$} & \multicolumn{2}{|c|}{$\begin{array}{c}\text { Mortality (\%) } \\
\text { (Mean } \pm \text { SE) }\end{array}$} \\
\hline & & & & $24 \mathrm{hr}$ & $72 \mathrm{hr}$ \\
\hline \multirow{4}{*}{$\begin{array}{l}\text { U-shaped } \\
\text { sprayer }\end{array}$} & \multirow{4}{*}{$\begin{array}{c}\text { Frankliniella } \\
\text { occidentalis }\end{array}$} & \multirow{3}{*}{$\begin{array}{c}\text { Abamectin } \\
1.8 \% \mathrm{EC}\end{array}$} & $5 \mathrm{~L}$ & $80.5 \pm 1.5$ & $82.8 \pm 2.5$ \\
\hline & & & $2.5 \mathrm{~L}$ & $82.5 \pm 1.8$ & $86.8 \pm 1.8$ \\
\hline & & & $1.25 \mathrm{~L}$ & $50.3 \pm 1.2$ & $59.3 \pm 2.5$ \\
\hline & & Con & - & 0 & 0 \\
\hline
\end{tabular}

Table 8. Attached amounts of Abamectin 1.8\% EC Spinetoram 5\% WG on the paprika in accordance with spray water volume

\begin{tabular}{|c|c|c|c|c|}
\hline \multirow{2}{*}{ Compound } & \multirow{2}{*}{$\begin{array}{c}\text { Application } \\
\text { dose (L/10 tree) }\end{array}$} & \multicolumn{2}{|c|}{$\begin{array}{l}\text { Amount of Compound } \\
\left(\mu \mathrm{g} / 50 \mathrm{~cm}^{2}\right)\end{array}$} & \multirow{2}{*}{$\begin{array}{c}\text { Average } \\
\left(\mu \mathrm{g} / 50 \mathrm{~cm}^{2}\right)\end{array}$} \\
\hline & & High position & Low position & \\
\hline \multirow{3}{*}{$\begin{array}{l}\text { Abamectin } \\
1.8 \% \mathrm{EC}\end{array}$} & $5 \mathrm{~L}$ & 8.09 & 17.47 & 12.77 \\
\hline & $2.5 \mathrm{~L}$ & 5.19 & 5.52 & 5.36 \\
\hline & $1.25 \mathrm{~L}$ & 6.03 & 3.8 & 4.91 \\
\hline \multirow{3}{*}{$\begin{array}{l}\text { Spinetoram } \\
5 \% \mathrm{WG}\end{array}$} & $5 \mathrm{~L}$ & 18.36 & 41.54 & 29.95 \\
\hline & $2.5 \mathrm{~L}$ & 21.81 & 35.78 & 28.80 \\
\hline & $1.25 \mathrm{~L}$ & 8.4 & 13.57 & 10.99 \\
\hline
\end{tabular}

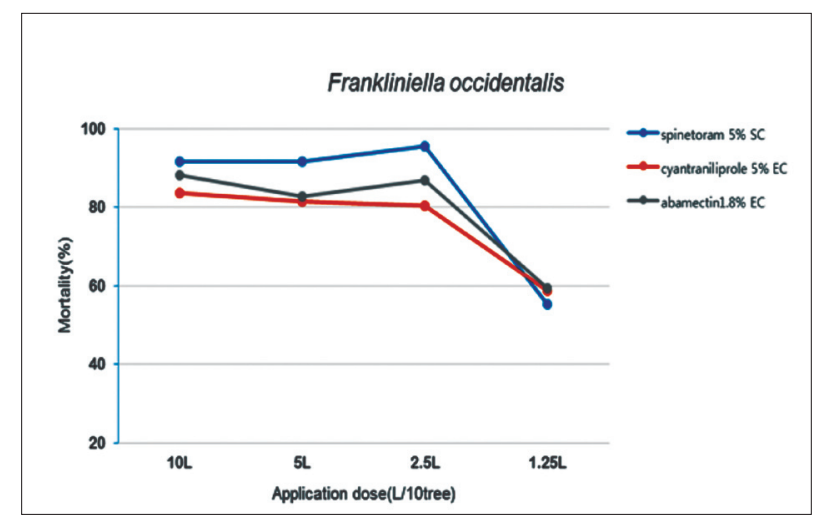

Fig. 2. Mortalities of Frankliniella occidentalis of pesticides with spray water volume.

approximately $82.5 \%$ after 24 hours and approximately 86.8\% after 72 hours. However, when $1.25 \mathrm{~L}$ were sprayed, lower control effects were identified, which reached approximately $50.3 \%$ after 24 hours and approximately 59.3\% after 72 hours (Table 7). To summarize the results from the three pesticides, the same high control effects were obtained when $5 \mathrm{~L}$ of the solution were sprayed and when 2.5 L were sprayed (Fig. 2). When pesticides are sprayed using high-pressure sprayers in paprika cultivation sites under structure, if there is no pesticide resistance problem, pest control effects of pesticides will not be reduced, even if lower pesticide solution volumes are sprayed. Standards for pesticide sprays in glass greenhouses should be studied comprehensively and should consider the sprayer type, the spray water volumes, and the ecological characteristics of pests.

\section{Amounts of active components of pesticides according to sprayed volumes}

Since pest control values are influenced by pesticide deposit degrees according to the volumes of pesticide solutions distributed using a high-pressure sprayer, the amount of active components attached were investigated using patches of $\alpha$-cellulose paper. According to the results, Abamectin 1.8\% EC showed high control effects, even when the average value of the active components was $5.36\left(\mu \mathrm{g} / 50 \mathrm{~cm}^{2}\right)$ when $2.5 \mathrm{~L}$ were sprayed per ten plants. Spinetoram 5\% WG also showed high control effects when the average value of the amount of active components was $28.80\left(\mu \mathrm{g} / 50 \mathrm{~cm}^{2}\right)$ when $2.5 \mathrm{~L}$ were sprayed per ten plants (Table 8).

\section{ACKNOWLEDGEMENTS}

This paper was prepared based on the results obtained when performing the task [Standardization of Spraying Equipment, Methods, Grouping of Containers, and Formulation in Using Pesticide PJ010043] under the joint research project of the Rural Development Administration.

\section{REFERENCES}

Cho, K. S., S. J. Jung, D. Y. Lee, Y. J. Kim, K. Y. Kim, B. K. Chung and K. Y. Kang 2011 Persistence of chlorfenapyr in paprika leaf and its residual biological activity to two spotted spider 
mite, Tetranychus urticae. Korean J. Pestic. Sci., 15: 317322

Choi, B. R., S. W. Lee, Y. H. Song and J. K. Yu 2005 Effect of sublethal doses of imidacloprid on the green peach aphid, Myzus persicae. Korean J. Pesti. Sci., 9: 374-379

Chung, C. J., K. G. Lee, J. Y. Rhee, S. I. Cho, Y. S. Choi and J. S. Choe 1997 An experimental study on coverage characteristic of a self-propelled boom sprayer for paddy field. J. Korean Soc. Agr. Machinery, 22: 137-150

Jin, N. Y., Y. K. Lee, B. R. Lee, J. H. Jun, Y. S. Kim, M. J. Seo, C. H. Lim, Y. N. Youn and Y. M. Yu 2014 Pest control effect and optimal dose by pesticide dispersion spray method in the paprika cultivation. Korean J. Pestic. Sci., 18: 350-357

Kim, J. H., H. Y. Kim, Y. H. Kim, Y. H. Lee and M. S. Lee 2008 Field application program for the biological control of the pests on sweet pepper (summer culture type). Ann. Res. NIAST (Agricul. Biol. Res.): 1827-1839

Kim, E., H. Lee, H. H. Choi, J. K. Moon, S. Hong, M. Jeong, K. H. Park, H. Lee, A. X. Hua and J. H. Kim 2011 Methods validation for monitoring of agricultural worker exposure to insecticide Fenthion. Korean J. Pestic. Sci., 15: 357-365

Kim, Y. J. 2012 Residual characteristics and efficacy of neonicotinoid insecticides for early pest control on paprika by different application methods. Master's thesis. Gyeongsang National
University Graduate School

Kim, K. D., S. W. Lee, E. H. Kang, Y. G. Shin, J. Y. Jeon, N. Y. Heo and H. S. Lee 2013 The pests survey of paprika export complexes and packing house in Korea. CNU. J. Agric. Sci., 40: 93-99

Koo, Y. M. 2007 Spray Deposit Distribution of a Small Orchard Sprayer. J. Biosystems Eng., 32: 145-152

Korea Crop Protection Association 2015 Pesticide testing personnel training book. 149-193

Lee, D. Y., Y. J. Kim, S. G. Kim and K. Y. Kang 2013 Residual characteristics of insecticides used for oriental tobacco budworm control of paprika. Korean J. Environ. Agric., 32: 84-93

Min, Y. B., J. C. Park, M. R. Huh and S. W. Jeong 2007 Effect of spraying the ultra-fine droplets of insecticide on control of the imported insects subsist on peppers in greenhouse. Korean J. Agric. Life Sci., 41: 89-94

Shim, J. Y., J. S. Park, W. H Park and Y. B. Lee 1997 Studies on the life history of green peach aphid, Myzus persicae (Homoptera). Korean J. Pl. Prot., 16: 139-144

Son, K. A., T. K. Kang, B. J. Park, Y. D. Jin, G. H. Gil, C. S. Kim, J. B. Kim, G. J. Im and K. W. Lee 2012 Effect of pesticide residues on perilla leaf by nozzle types of knapsack sprayers. Korean J. Pestic. Sci., 16: 282-287 